\title{
The Racialization of the Indigeneity of Others
}

\author{
Sandra Khor Manickam, Taming the Wild: Aborigines \\ and Racial Knowledge in Colonial Malaya
}

Honolulu: Asian Studies Association of Australia/University

of Hawai'i Press, 2015. 384 pp. \$35.00 paperback.

\section{Fenneke Sysling, Racial Science and Human Diversity in Colonial Indonesia}

Singapore: National University of Singapore Press, 2016. vii+305 pp. $\$ 42.00$ paperback.

\section{Ricardo Roque}

Racial conceptions pervaded modern colonial regimes of power throughout Southeast Asia. Scholars working today on colonial histories in this region would hardly contest this statement. European imperial expansionism and European racial imaginaries are each part of the same political field; they share a common history and as such they should be examined together. In this vein, in recent decades there has been increasing interest in how the production and circulation of race constructs - whether evocative of purity or mixture, of an elusive whiteness, or of primitive aboriginality/ies, for example - might frame, even construct, colonial and national regimes of power. In particular, scholarly interest has been growing in the historical study of the so-called racial sciences, a plastic designation under which one may encompass a variety of selfproclaimed scientific knowledge practices - from medicine to (physical) anthropology, the nineteenth-century science of race par excellence.

Taming the Wild by Sandra Khor Manickam, and Racial Science and Human Diversity in Colonial Indonesia, by Fenneke Sysling are two recent historical monographs that represent this emerging trend. In colonial Southeast Asian histories, the racialization of others and of oneself could take on a number of distinct manifestations, central to which were the tropes of whiteness, hybridity, and autochthony (Anderson and Roque 2018). The two works reviewed herein, however, focus

\section{R. Roque}

Instituto de Ciências Sociais, Universidade de Lisboa, Portugal

ricardo.roque@ics.ulisboa.pt 
exclusively on the latter theme; they explore how the Europeans crafted scientific and colonial categories of racially pure, originary, indigenous identities of otherness.

In British Malaya and the Netherlands East Indies, the works hypothesize, scientists and colonial administrators were driven less by the questions of who was racially white or who was racially mixed than they were by the problem of who was racially indigenous. Of course, in the Asian colonial world, European concepts of race were not limited to ideas of "primitive" or originary otherness, nor were they contained merely within scientific discourses. Race was ubiquitously omnipresent in the semantics of colonial regimes. "The colonial politics of exclusion," Ann Laura Stoler (1989: 635) lucidly wrote in one of her seminal writings on this topic, "was contingent on constructing categories, legal and social classifications designating who was 'white,' who was 'native,' who could become a citizen rather than a subject . . . who counted as 'European' and by what measure." Modern European racial regimes of colonization were at their most dramatic with regard to the (re)production of "whiteness" and the management of "interracial mixing" in the colonies - and scientific practices were not simply external to this process.

The authors of the two monographs under review could have taken this dimension into greater consideration. In any case, by calling attention to the lasting obsession of European colonizers with indigeneity as an expression of racial alterity, these two works add significantly to the literature on racialization histories in Southeast Asia. To begin, then, we have before us two fine books and well-researched monographs. At the core of both works is a shared historical inquiry into what I suggest designating as the colonial and scientific modes of racialization of the indigeneity of others, that is, the colonizers' practices and knowledge forms concerned primarily with the production of pure and "primitive," "indigenous," or "aboriginal" racial identities as the attribute of Southeast Asian otherness.

Manickam's Taming the Wild is a history of racial ideas that follows the making of British concepts of aboriginality in the territories under British colonial rule in the Malay Peninsula between the late 1700s and the 1930s. Sysling's Racial Science and Human Diversity is a history of racial science that traces the birth, development, heyday, and demise of Dutch physical anthropology in the colonies designated as the Netherlands East Indies from the 1870s to the 1950s. These two parallel histories restrict each of their respective empirical fields to the British and Dutch national imperial networks and archival materials. Interimperial and transcolonial comparisons and connections in the region are underexplored; and readers of the two books may wonder about possible crossings and circulations between and across the two neighboring cases of British and Dutch colonial histories. The two books, then, rarely venture beyond their respective British-colonial and Dutch-imperial national histories. However, read together, they provide rich material for wider reflection beyond the specific cases. In the following, I attempt a possible dialogue between the two works, highlighting some of their comparative achievements with regard to one underlying issue: the dis/continuities between scientific and colonial knowledge and, in particular, the question of how, or even if, racial sciences participated in the racialized colonial technologies of knowledge and rule that targeted the presumed "aborigines."

Taming the Wild explores the colonialist and racialist intellectual genealogies of the Orang Asli category. In contemporary Malaysia, this term appears often in opposition to the category Malay and is commonly used to refer to the "first," "authentic," and 
presumably "backward," indigenous forest-dwelling peoples of Malaysia. The book historicizes this Malay/Orang Asli dualism by looking at the changing British "strands of thought," or "streams of discourse" (6) concerning indigeneity in Malaya since the late eighteenth century. In particular, the book is concerned with examining the changing patterns of continuity and discontinuity between "colonial government" and "anthropological" (a.k.a. scientific) racial discourses on the aborigines. The metaphor of "racial knowledge as a form of taming" (8) is mobilized to capture the ways through which knowledge about "wild aborigines" intimately connected to the administrative desire to control, domesticate, and voraciously extract resources from indigenous people and land. The book first examines the origins of a British discourse on indigeneity in the works of late eighteenth-century philologists. These early views of indigeneity were based on language; they did not imply hierarchy and were mainly evocative of ideas of primordiality. By the mid-1800s, however, this more neutral notion changed dramatically to include ideas of biological, social, and civilizational "inferiority" and "primitivism." This period also saw important changes that led to a foundational classificatory split between the categories Malay and non-Malay "Aborigene" [sic]. The latter, then, "began to be seen as a race or a group of races different from, and less developed than, Malays" (13). This intellectual change was decisive for subsequent anthropological and colonial administrative studies, which continued to follow per this divide.

The book explores mainly British texts and records where "Orang Asli perspectives are still, for the most part, missing" (5). Racialized categories of indigeneity were defined by the Europeans or by the holders of colonial power - they were not markers of identity created by the indigenous people themselves. To glimpse at local Malay agency in the production of European racial discourses, however, Manickam also considers Malay notions and the intervention of Malay intermediaries. In one of the most original-thinking chapters, the book investigates whether Malay concepts in particular might have entered into European racial constructs. "One cannot write on the history of ideas about Malaysia's indigenous people," the author aptly observes, "without considering how indigenous people have been written about in Malay" (44). This challenge is pursued through an analysis of Malay-language texts and concepts of human difference in the nineteenth-century writings of Munshi Abdullah. From this study, Manickam concludes "there were other [Malay] categories and logics" (42), "several ways of perceiving difference in humans . . . that did not pivot around the English meanings of race and aborigines," and which were not incorporated into British texts (43; italics in original). Thus, British ideas of aboriginality and race constituted provincial Western constructs that only with difficulty found accurate equivalents in Malay words and constructs of human difference. From the late 1800s, however, English texts redefined and appropriated the Malay term Sakai to become the generic category for aborigines. Chapters 3 and 4 explore the making of the racial dualism of Malay versus Sakai as well as the making of yet another racial dualism internal to the Sakai category ("tame" Sakai versus "wild" Sakai) in late nineteenth- and early twentieth-century colonial government knowledge. A wealth of colonial texts and forms of data gathering is analyzed, including colonial scholarly journals and, importantly, the colonial censuses. British indirect rule relied on a network of ties and treaties with Malay polities. Dealings with so-called Malays were thus 
paramount to the pragmatics of colonial government. For this reason, the writings of colonial administrators tended to approach "indigenous people as an appendage to the Malays" (73).

Manickam observes a contrast between the colonial government fixation on Malays, and the emerging scientific obsession of anthropologists with the "primitiveness" of the aborigines. In the colonial sphere, constructs of aboriginality derived from a diffuse "colonial common knowledge" (4) that presumed a civilizational gradation from "wild" to "tame" aborigines, the latter closer or ideally ultimately juxtaposed to the so-called Malays. Even in the censuses, this colonial common sense took the lead and scientific understandings of aborigines "played only a secondary, if not minor, role" (109). In fact, Manickam argues, colonial and scientific racial understandings of aborigines often went separately. "The understanding that aborigines were on a gradient with Malays profoundly influenced the governmental view of aboriginal extinction, a view vastly dissimilar from that in anthropology" (125). Colonial and scientific racializations configured two "systems of differentiation" (125) that seemed to come rarely, if ever, into classificatory, let alone theoretical, communication and agreement. Anthropological categories, for instance, would ignore the ubiquitous "tame" aborigine category, which was otherwise central to colonial racializations. For, whereas scientific categories of aboriginality would sometimes blend with or somehow absorb the common sense of colonial racial knowledge, the opposite was not true. The racial categorization derived from anthropometrics did not easily find room in the administrative apparatus. Chapters 5 and 6 explore this important point further in the scientific writings of colonial physical anthropologists W. W. Skeat and Ivor Evans. By 1900, Skeat headed an ambitious expedition sponsored by Cambridge anthropologist A. C. Haddon that aimed at rigorously classifying the diverse indigenous races of the peninsula. Yet the anthropometric knowledge and the race categories produced by the expedition hardly penetrated the government realm. "The application of . . . methods and ideas from physical anthropology," concluded Manickam, "produced specific framings of indigenous people that, while connected to the systems of differentiation found within the census, were nonetheless distinct and based on different criteria" (127). The scientific and the colonial ended up constituting two parallel and sometimes "incompatible" (187) regimes of racialization of indigeneity, partly overlapped and coexistent, yet also disconnected and separate.

A comparable concern with the continuities and discontinuities between racial science and the power structures of modern colonialism traverses Sysling's historical study. In the wake of practice-oriented approaches in the history of science, Sysling is less interested in tracing dis/continuities in intellectual patterns and ideas than she is in investigating them in the realm of concrete practices and interactions. The book thus emphasizes the fragile, variable, and contingent nature of race as an artifact of "the encounters between European scientists and indigenous people" as well as of the arduous technical labor of self-titled scientific Dutch "experts" in race science. "It was 'on the ground,' in the Indies," Sysling proposes, "that expectations were or were not met, where encounters with individuals shaped ideas about difference or where measuring sessions were skewed because not everyone agreed to be measured" (2). Dutch field racial science in the Indies found inspiration in French and German anthropology models. It was above all concerned with classifying the "human diversity" of the so-called pure indigenous races that inhabited the Dutch colonial possessions. The 
aggressive territorial expansionism that characterized Dutch colonization in Southeast Asia from the 1890s onward made the Dutch race scholars' ambition possible. Thus the Dutch scientific project of pluralistic racialization of indigeneity/ies mapped onto the colonial empire. It also depended on a highly trained and technical form of specialized anatomical knowledge that claimed superior objectivity from the application of a specific set of field and museum methods of observation and analysis - among which were craniology, anthropometry, plaster casting, and photography most famously.

Drawing on a wide array of Dutch public and private archival materials, the book discusses each of these different methods of making race, and follows how the main Dutch racial anthropologists working in and on the "races" of the East Indies put these methods into practice. The first part explores respectively the colonial collecting of human skulls, the field practices of anthropometric measurement, and the production of casts and photographs of indigenous people. The second part of the book examines personal trajectories, between metropole and colonies, of three prominent race scholars: Hermann ten Kate's fieldwork in the Timor Archipelago driven by the problematic of Alfred Russel Wallace's ethnological line, Kleiweg de Zwaan's (that all-powerful figure of Dutch colonial physical anthropology) extensive studies in the region, and Hendrik Bijlmer's expeditions in search of Pygmies in Dutch New Guinea. Throughout her study, the author pays close attention to the different types of encounterinvolving violence, but also negotiation and persuasion - that structured anthropological colonial research; and, based on textual materials alone, Sysling perceptively recovers forms of indigenous agency and resistance. In spite of the enormous labor involved, however, Dutch racial science ultimately was a failed project. In many cases racial "ideas were also frustrated or forgotten" (2); in the end, for physical anthropologists themselves, indigenous race(s) was a ubiquitous notion that they never managed to pinpoint.

Sysling also makes the case for a tensional ambivalence between Dutch physical anthropologists and Dutch colonization. On the one hand, she argues, anthropologists depended on the institutional structures, political opportunities, and power apparatuses of colonial administration to gain access to indigenous skulls, skeletons, and living bodies. On the other hand, as "salvage anthropologists," they "tried to avoid" colonial structures with a view to make contact with idealized pure and isolated races, allegedly untouched by "civilization" and miscegenation (48). Dutch colonialism as a biopolitical power structure was thus more important for physical anthropologists than physical anthropologists were for the workings of colonial government. Moreover, the Dutch race science of diverse racial indigeneities was largely secondary and often irrelevant to the actual functioning of colonial government. Sysling presumes both colonialists and race scholars shared a diffuse "racialized common sense" (10), yet she also suggests the Dutch experts' obsession with purity and indigeneity apparently stood in stark contrast with the colonial concern with miscegenation and mixed-race identities, which dominated debates in the legal and administrative sphere in the Indies. In this light, it is perhaps revealing that physical anthropology and government issues met only for a moment in the 1920s and 1930s, when Dutch environmentalists allied with Bijlmer to critique the colonial policies and claim from the government the (unsuccessful) creation of a reserve for New Guinean highlanders. "Physical anthropology," Sysling concludes, "fitted uneasily in the Dutch imperial project. Even though promises of eventual usefulness were an important part of anthropological rhetoric, 
anthropologists hardly ever made their knowledge useful for colonial policy" (179). This resonates with Manickam's similar point on British Malaya: "Although the overall influence of anthropology on government was minimal," Manickam writes, "official government work was an enabling factor for anthropological research into indigenous peoples" (170).

While Taming the Wild emphasizes relative dis/continuities in colonial versus scientific intellectual constructs of race, Racial Science and Human Diversity draws attention to relative dis/junction in colonial versus scientific infrastructural orientations to the racialization of "natives." Thus, taken together and read comparatively, both works contribute to a more nuanced appreciation of the internal complexities of the connected worlds of European science, race, and colonialism in Southeast Asia. Both studies imply that in spite of their differences race science and colonial knowledge shared one same "racialized common sense" as regards the indigenous Other(s). This proposal of an unspecific and unfixed common sense, however, is perhaps too loosely conceptualized. Though they simultaneously claim that this diffuse harmony was often only partial, ultimately it did not translate into consensual classificatory systems or instrumental incorporations of racial science into the British and Dutch colonial apparatuses of government. Thus without discounting the violence of colonial racial regimes, both works concur that to simply assume race science was directly instrumental for colonial government is misleading. The colonial and the scientific racialization(s) of the indigeneity of others, one may hypothesize, did not form one internally coherent and homogeneous system. Racialization was certainly insidious and pervasive, but it was messy, eclectic, adaptive, contested, and contradictory at multiple sites. "Race," Achile Mbembe (2017: 11) provocatively asserted in his critique of the resilience of colonial racisms, "is an autonomous figure of the real whose force and density can be explained by its characteristic mobility, inconstancy, and capriciousness." Hence the malleable, dissonant, and incoherent configurations of the racialization of indigeneity, as identified by Manickam and Sysling, do not necessarily read as sign of failure. Instead, I think they point to an important way through which the "race" artifact operated successfully in the politics and social life of colonial regimes.

Finally, the two works also call attention to how this complex and confused world of colonial racialization left enduring and lasting presences in postcolonial societiesbeyond the period of decolonization in Southeast Asia and beyond the end of empires in Europe. Manickam signals the intellectual resilience of racialization over time. She concludes that former racial imageries survive in Malaysian stereotypes of Orang Asli otherness, and in governmental, capitalist, and scientific extractive practices that target the lands and bodies of forest dwellers. In a complementary vein, Sysling observes the material and institutional longevity of physical anthropology in the Netherlands, as revealed, for instance, in the numerous collections of anthropometric data and human skeletal remains from Southeast Asians still held by Dutch institutions in Europe.

In the Southeast Asian past, the notion of indigeneity began as a racialized concept of imaginary otherness, within the framework of European colonial regimes. This racial idiom, as both works suggest, came into being as a one-sided European or government-oriented production. In recent decades, however, the term indigeneity has gained more positive connotation as a self-empowering identity signifier for many formerly colonized minorities and communities, who fight against the impact of past and present forms of colonial and neocolonial exploitation. Coming historians 
may wish to consider further how, or even if, such current identity/alterity struggles around indigeneity transform and rearticulate the racial imaginaries of the colonial past. They may also do well to move beyond the straitjacket of European racial imagination to consider the autonomous action and conceptions of indigenous subjects. For instance, it would be worth investigating racial constructs in relation to indigenous cultural conceptions of autochthony and alterity; and how those once labeled aborigines engage with the racial discourses of indigeneity as alterity on their own sociocultural terms - ignoring, appropriating, or subverting them, for example. These remarks do not diminish the value of these two works. It is among the joint merits of Taming the Wild and Racial Science and Human Diversity to have exposed the colonial and racial genealogies that produced Southeast Asian "indigeneity" in the past — and which continue to exert their force in the present. New scholarship on the critical history of comparative racialization in Southeast Asia will benefit importantly from their contributions.

\section{References}

Anderson, Warwick, and Ricardo Roque. 2018. "Imagined Laboratories: Colonial and National Racializations in Island Southeast Asia." Journal of Southeast Asian Studies 49, no. 3: 358-71.

Mbembe, Achille. 2017. Critique of Black Reason, translated by Laurent Dubois. Durham, NC: Duke University Press.

Stoler, Ann Laura. 1989. "Making Empire Respectable: The Politics of Race and Sexual Morality in 20thCentury Colonial Cultures.” American Ethnologist 16, no. 4: 634-60.

Ricardo Roque is a research fellow at the Institute of Social Sciences at the University of Lisbon and an honorary associate in the Department of History at the University of Sydney. He works in the history and anthropology of colonialism, human sciences, and cross-cultural contact in the Portuguese-speaking world. $\mathrm{He}$ is the author of Headhunting and Colonialism (2010). Among his edited collections are Engaging Colonial Knowledge (with Kim A. Wagner; 2012), Luso-Tropicalism and Its Discontents (with Warwick Anderson and Ricardo Ventura Santos; 2019), and the special issue Imagined Laboratories: Colonial and National Racializations in Island Southeast Asia of the Journal of Southeast Asian Studies (with Warwick Anderson; 2018). 